\title{
A Microeconomic (Vintage) Model of a Shipping Company: A Proposed Depreciation Strategy
}

\author{
Alexandros M. Goulielmos ${ }^{1,2}$ \\ ${ }^{1}$ Marine Economics, Department of Maritime Studies, Faculty of Maritime and Industrial Studies, University of Piraeus, \\ Piraeus, Greece \\ ${ }^{2}$ Shipping, Transport and Logistics Department, Business College of Athens, Athens, Greece \\ Email: ag@unipi.gr, am.goulielmos@hotmail.com, agoulielmos@bca.edu.gr
}

How to cite this paper: Goulielmos, A. M. (2021). A Microeconomic (Vintage) Model of a Shipping Company: A Proposed Depreciation Strategy. Modern Economy, 12, 1185-1212.

https://doi.org/10.4236/me.2021.128062

Received: May 27, 2021

Accepted: August 9, 2021

Published: August 12, 2021

Copyright (c) 2021 by author(s) and Scientific Research Publishing Inc. This work is licensed under the Creative Commons Attribution International License (CC BY 4.0).

http://creativecommons.org/licenses/by/4.0/

Open Access

\begin{abstract}
We dealt with an important part of fixed cost, i.e., the depreciation expense in managing a shipping company owning 20 intangible fixed assets (ships), characterized by different vintages (ages), and book values. Keynes drew our attention to the importance of capital for the economy, and he dealt with the ways not only to increase it, but also to keep it in tact, through replacement. When economists tried to make Keynes dynamic, however, (known as Keynesian growth theory), they faced with the problem that not only capital's productivity depends on capital's vintage, but also its embodied technical progress depends on age. In shipping, we use the concept of "sister ${ }^{1}$ ship". We used also a questionnaire on shipping depreciation filled-out by 45 Greek shipping companies. The existing theory of depreciation is, for shipping, wrong, we believe! While accountants want capital to be replaced after its death, they "condemn" shipping firms to end, prematurely, when a severe cycle occurs! Depreciation is related to gross profits, instead of to market's conditions! Thus, we proposed an alternative shipping depreciation policy, using also an inexpensive statistical tool-a regression line-between ship age and price. When accountants etc. proposed depreciation for the first time, they ignored cycles, inflation and (shipping) depressions! We were surprised to find-out that economics ... forbid "economies of scale", when average cost exceeds marginal cost, $\mathrm{AC}>\mathrm{MC}$ ! Any society which wants a faster growth, has to adopt embodied technical progress, reducing both capital and labor, than hitherto, and especially capital! Moreover, Society committed the mistake to create unequal income and wealth since Keynes's time (1936), something which re-appeared in its most grandiose form in 2019-2021,
\end{abstract}

\footnotetext{
${ }^{1}$ A "sister ship" is the ship which is exactly the same as one or more previously ordered ships, for the benefits that this strategy offers. We may call them ships produced in series or in pairs with identical specifications. They could be better named twin ships. Their vintage may differ in months one after the other.
} 
among a crisis and a pandemic, providing $\$ 13.1$ trillion to just 2755 fellow citizens only, worldwide!

\section{Keywords}

Vintage Models in Growth and Shipping, A New Depreciation Strategy, The World Economy and the Creation of New Rich, New Poor, New Homeless and New Jobless, Adam Smith's Invisible Hand, Regression between Ship's Age and Price

\section{Introduction}

Economists distinguish Economics into: "Macro" and "Micro", the latter known also as "Price Theory"2. Micro is a Greek word meaning small. A company e.g., is small compared with the economy. Such a unit is also the consumer (on the side of consumption).

Economists tried to find out how a producer recovers his/her cost of production plus a profit. A company, we believe, needs a motive in order to embark on the production of the means for the satisfaction of the needs held by consumers. This motive is to gain "something" above cost of production. Adam Smith (1910) argued that this endeavor is governed by the "invisible hand" ... In fact, Adam Smith (1723-1790) "beatified" the profit motive (1776), we believe, by inventing "the invisible hand" (book 4 ; chap. 2)!

Blaug (1997: p. 57) argued that Smith's “invisible hand" is nothing else, but the "automatic equilibrium mechanism of competitive markets"! This... third invisible hand invented by economists to demonstrate that for all economic evils one has to blame the interference with the economic system (in a perfect competitive environment). We all have witnessed, however, the failure of markets at times like the one in end-2008. Also, the collapse of world health followed 11 years later, in 2019, but for which we cannot blame economists!

Earlier writers employed the metaphor of the invisible hand as to mean the "hand of God"! If so, Smith was confused, we believe, by the harmony observed in Nature, and in Universe, and thought that similar conditions had to prevail in human economic affairs! But though the Nature and Universe were constructed by someone highly superior (the "Superior Mind"), human affairs are determined by the free will (Priesmeyer, 1992).

One pillar, i.e., "human justice" applies to cases where the same rules hold for everyone, and no one is supposed to be favored, i.e., there is an impartial system. The divine attitude of justice, however, is favorable to all, providing the exact application of what was right in some latter time, if one finally is going to be disciplined by it... Thus, one has three invisible hands (divine, human and that of the market).

${ }^{2}$ Bilas (1967: p. 1). 
Another pillar of the human system is that one has to work, and to work hard! We do not know what economic theory Smith would have written, if he knew that the two systems, (divine and human), were not converging. This does not mean that the human system has not to converge to divine... at least in matters of solidarity... especially the last 2 - 3 years.

We come now to another issue, which has tortured economists for centuries: Can we define profits? Is this a price, which consumers/ users have to pay so that to have firms - willingly—to produce the needed goods and services? In fact, if a company earns a low or zero gross profit, means that depreciation-our main topic-will be low, or zero. Thus, firm's capital could not be replaced ${ }^{3}$, and these specific goods/services would not be produced!

Economists avoid defining the exact \% of profits, and especially normal ones... Many confuse also what super-normal profits are, as they have to be... zero (defined below). Keynes defined profits (mentioned below).

Objectively speaking, a scarce good has to demand a higher price, as many ask for it, but... few can have it. Something most-wanted it will demand a higher price, logically. But Economists based everything on scarcity. But as we have argued elsewhere even an affluent economy requires economics (Goulielmos, 2018).

The dual role of demand and supply in determining price, confused the first economists. Some argued that cost only determines price, and others that demand only determines it. Marshall (1920) (1842-1924) solved this dilemma in 1890 by arguing that both demand and supply determine price in exactly the same way that a pair of scissors cuts a piece of paper...

\section{The Aim and Organizing of This Work}

The main aim of this paper is to compare the microeconomic theory of the firm with the microeconomic theory of a shipping company in the making. For this purpose, we shall use a specific arithmetical and diagrammatical case-study, the data for which we found in the literature (Stopford, 2009: pp. 330-335).

The paper is organized in parts, after literature review. Part I, dealt with the outstanding faults of Economic Society; Part II, dealt with shipping vintage models; Part III, dealt with one particular microeconomic shipping vintage model; Part IV, dealt with the strategy of depreciation in shipping companies; finally, we conclude.

\section{Literature Review}

Ricardo (1951-1973) (1772-1823) argued (Chap. 1) that part of labor is employed also to maintain capital intact, and thus depreciation costs are wage costs, depending on capital's useful life. Marshall (1920: p. 295) (1842-1924) argued that depreciation is caused by: wear and tear; elements' influence; new inven-

${ }^{3}$ Fashion, preferences, tastes, boredom, new products and services, and passions, habits and customs, are the common reasons to reject a product or a service; though fashion, as they say, returns. 
tions and changes in trade.

Keynes (1936: p. 69) (1883-1946) defined depreciation ${ }^{4}$ - part of user cost-in line with Revenue authorities (Hansen, 1953: p. 57), calculated on the original cost of the equipment. The user $\operatorname{cost}^{5}$ is:

$$
U=\left(G^{*}-G\right)+A_{1}
$$

where

$$
G^{*}=G^{\prime}-B^{\prime}
$$

Keynes believed that firms do not use first their oldest, and worst, equipment, because user cost is low, because the factor cost may be high (Table 2 confirmed this).

In shipping, placing capital idle (laying it-up) is not without a cost, while age increases (i.e., a double cost). The use of capital in providing income below average variable cost-AVC, leads to shut down. Keynes ${ }^{7}$ wrote that one firm has to consider the status of capital if not used today and used tomorrow (p. 70). The profit for Keynes is equal to the value of the output A sold, minus the factor and user cost:

$$
A-(F C+U)=\text { Profit . }
$$

In shipping industry if a ship is not used, her services are gone ... as they cannot be stored.

Robinson (1966) (1903-1983) argued that entrepreneurs must create an amortization fund-out of working proceeds. Robinson and Eatwell (1973: pp. 134-135) argued that a firm must recover enough from the returns that a machine provides over its earning lifetime. So that to be able to invest it in another machine, of at least equal value, when the profitable life of the old one comes to an end. The net profits are arrived by subtracting sufficient obsolescence allowances from gross profits so that to maintain the value of the investment...

Cheng (1979: pp. 160-163) argued that depreciation is not a measure of the

${ }^{4}$ Townsend (1995: p. 14) argued that the intensive use of capital increases depreciation; and it sacrifices future net receipts. Interest on owners' capital is not a cost for accountants, but for economists. ${ }^{5}$ This is the money spent in the production of $A$ ( $A=$ sales): $G$ is Capital's value, in real terms, at the end of the period; $A_{1}$ are the purchases from other firms; $B^{\prime}$ is what is spent for capital's maintenance and improvement; $G^{\prime}$ is the value of $G$, if not used, after $B^{\prime} . G^{*}$ is the maximum of capital's net value, which received from previous period. In $G$ Keynes included working capital, finished and semifinished products. The value due to the capital of the previous period if subtracted from current income of the firm, along with purchases from other companies, and if the value of $G$ is added to Sales, we arrive at income:

$$
\left(A-A_{1}\right)+\left(G-G^{*}\right)=C+I=Y .
$$

Factor cost $\mathrm{F}$ for Keynes for sales $\mathrm{A}$ is the amount paid to other factors of production for their services.

${ }^{6}$ Firms hire "factors of production", or buy "inputs". Bunkers expenses e.g., for ships is an important input though is not a classical factor of production like capital, labor and land or sea (which is free, except for crossing canals and visiting ports)!

${ }^{7}$ Keynes referred also to... ships! The User Cost of a ship, in over-supply, meant, for Keynes, that we have to estimate the cost of her replacement, and discount it by using the ruling rate of interest plus the current supplementary cost. And this for a time needed for the oversupply to be absorbed. 
decline of the market value of a ship, or a process of ... generating money to replace a particular ship, but to reduce the book value of an aging ship to its salvage value at replacement; but that money, may not be enough. He mentioned a method called "activity" one, which is close to ours. The "activity method" is based on an estimated economic life in terms of output, where depreciation follows the revenue curve. At his time, in USA the ocean-going ships were amortized in 20 years, less 5\% salvage value; Japanese applied 15 - 20 years and UK 20 years, except for tankers etc., which was 15 years.

In a Lloyd's of London Press (1988) conference, Mr. Dawes argued that depreciation funds may be substantial in certain companies, like e.g., Exxon (in 1987). Exxon on $\sim \$ 48$ b Gross profits, had a depreciation of $\sim \$ 4.5 \mathrm{~b}$ or $9.4 \%$. His Gotaas-Larsen company, however, applied $\sim 19.3 \%$ ! On $\$ 188.5 \mathrm{~m}$ gross profits, depreciation was $\$ 36.4 \mathrm{~m}$. He stressed that capital intensity ties-up liquidity, and a shipping company has to turn a ship into a liquid asset! This means that by making serious gross profits, a company may stay liquid by retaining a serious $\sim 20 \%$ of them for depreciation... This is close to our line of thought.

Evans (1989) dealt with the replacement of ships. His approach based on costs, instead of on profits. Capital cost and the operating one have the most important influence. In our opinion his model can be used supplementarily with one based on profits. His objective was to determine the optimum life of a ship, defined as the time elapsed between ship entering service and when her average total annual cost-ATC p.a., reached a minimum.

Buckley (2008: p. 43) argued that depreciation is an annual provision made by a prudent owner to write-off the value of the units of his/her fleet, usually based on a theoretical 20-yearly life. In the tramp trade, the inconsistent earnings may not be enough to provide a $5 \%$ of ship's purchase price (a good financial practice of 20 years). Some owners cut down the book value of their new ships as much as possible, for the first 2 - 3 years, and then do as earnings permit. The sooner a ship is written-off, the faster the owner may compete for cargoes in bad years, he argued.

Stopford (2009: p. 239) argued that the equity investors in public shipping companies are interested in how much depreciation a listed company is going to apply. Ships are subject to wear, and this is handled usually by (a "straight-line") depreciation.

Summarizing, we saw no argument in favor of applying a depreciation, except for the expectation to replace a vessel after her scrapping. One reason might be: "if consumers/users wish the products/services of a company to be supplied also tomorrow, they have to buy them now allowing... an adequate gross profit". Shipowners e.g., want their firms to last, through depreciation. A Charterer may manifest-given market conditions-his agreement to this by providing them... enough profits. Charterers do not mean, we believe, to supply shipowners with such profits, so that to replace their capital with a ship other than a sister one ${ }^{8}$ !

\footnotetext{
${ }^{8} \mathrm{~A}$ sister ship is one which comes when a shipowner orders 2 units of the same size, type etc. at the same time.
} 
Depreciation depends on gross profits, and in case of cycles, like recessions and depressions, firms are perished pre-maturely, while their capital did not reach its non-useful life! So, although we say we want firms to be alive for a long time, through depreciation, we see them to disappear... during a crisis!! Contradictory!

This is why in this paper we proposed a depreciation policy-or amortization for British-to be in accordance... with market conditions, and not on the standard way which accountants want, i.e., insensitively to reality. Shareholders also wish less depreciation, but prudent managers, should prefer a sensible depreciation strategy, as proposed here. If saving ${ }^{9}$ is good for the economy, why depreciation not to be beneficial for a company? The improper depreciation, however, is not the only fault of economic societies!

\section{Part I: The Outstanding Faults of Economic Societies, 1936; 2021}

There are certain faults of the present and past economic societies. Extremely strange is to find-out that among a killing pandemic-as covid-19 (Table 1) - certain people became exceptionally richer... In other words, we saw the creation of "the New Rich"!

As shown in Table 1, we have taken as an example our country Greece, having a small economy, and about only $11 \mathrm{~m}$ people, to show the impact of covid-19, having killed about 12,000 persons by now. 206,000 companies have shut-down; the state's debt reached $340 \mathrm{~b} €$ in 2020 ; the GDP reduced by $27 \mathrm{~b} €$ in 2020. Except for internet businesses, hotels, retailing, restaurants, museums, cinemas and coastal shipping etc. suffered from greatly reduced incomes.

Moreover, Forbes announced in 2021, that 2755 persons globally-660 more $(+24 \%)$ than in 2020 -earned income $\$ 13.1$ trillion, i.e., $\$ 5.1$ tr additional (+39\%), during COVID-19! An economic miracle? Among those were: 493 new

Table 1. The Economy of Greece under COVID-19, 2021 (Feb.).

\begin{tabular}{|c|c|c|c|}
\hline Impact 1 & Impact 2 & Impact 3 & Impact 4 \\
\hline $\begin{array}{l}206,000 \text { companies } \\
\text { shut-up }\end{array}$ & $\begin{array}{l}550,000 \text { companies } \\
\text { received some kind of } \\
\text { support }\end{array}$ & $\begin{array}{l}1.2 \mathrm{~m} \text { employees } \\
\text { received some kind } \\
\text { of support }\end{array}$ & $\begin{array}{l}\text { The deficit reached } 7.2 \% \text { of } \\
\text { GDP or } € \sim 12 b \text { in } 2019 \text {; } \\
\text { Debt: } 209 \% \text { of GDP or } \\
€ 340 b(+9 b) \text { (in } 2020 \text { est.)! }\end{array}$ \\
\hline Impact 5 & Impact 6 & Impact 7 & Impact 8 \\
\hline $\begin{array}{l}\text { Growth of GDP: } \\
\sim € 163 \text { b (est. in } 2020 ; \\
\$ 189 \text { b) from } € 190 b \text { in } \\
2019 \text { ! Minus } € 27 b\end{array}$ & $\begin{array}{l}\sim € 42 \mathrm{~b} \text { less turnover by } \\
\text { companies; minus } 20 \% \\
\text { of retailing business } \\
\text { (-€2.1b); minus } \sim 38 \% \\
\text { of restaurants' etc. } \\
\text { turnover (-€2.1b) }\end{array}$ & $\begin{array}{l}\text { Internet sales }+165 \% \text { - } \\
\text { the only positive! }\end{array}$ & $\begin{array}{l}4 \text { out of } 5 \text { hotels of } \\
\text { continuous operations, } \\
\text { remained closed; turnover } \\
€ 1.8 \mathrm{~b} \text { from } € 8.4 \mathrm{~b} \text { (minus } \\
€ 6.6 \mathrm{~b} \text { ) }\end{array}$ \\
\hline
\end{tabular}

Source: Greek weekly press “Kathimerini” 21/02/2021. Especially were hit: museums, cinemas, concert halls (€30b less revenue) and coastal shipping.

${ }^{9}$ Joan Robinson (1966) talks about the "amortization fund", which has to earn also interest. 
rich, of which 210 from China, and 98 in USA. Bezos J, e.g., collected \$177b; Musk E \$126b (Tesla); Arnault B \$150b; followed by Gates B and Zuckerberg M. Most of them located in the Silicon Valley.

Shipowners were not equally rich, despite of what is believed: Hapag-Lloyd was at the 58th world position with $\$ 26.3 \mathrm{~b}$; Saade (containerships) at $203^{\text {rd }}$ position with $\$ 23.4 \mathrm{~b}$; Aponte at $208^{\text {th }}$ position with $\$ 11 \mathrm{~b}$ and Fredriksen at $216^{\text {th }}$ position with $\$ 10.4 \mathrm{~b}$.

Economists further involved into the more difficult problem of producing the "optimal combination of products" by the most efficient (technically) combination of means (inputs)! While efficiency is quite a straightforward concept, as it requires to achieve the maximum result (output) by devoting the least means (inputs), both in money terms, what is optimality? It is also strange given that society asks from managers efficiency, and from economists, optimality! This is because efficiency is only one criterion for the optimum ... and a "just distribution of income" is another...

Some argued that to "satisfy one's desires" is... the objective of the economic system... (Pearce, 1992). But there is: the scarcity of goods, and of resources, and the limits imposed by incomes... Pareto proposed his optimum: when a re-distribution of income makes someone better-off, without making any other worse-off...

USA administration argued that the end-January 2021 inequality ${ }^{10}$, cost $\$ 1$ tr p.a. and created $1.2 \mathrm{~m}$ jobless! Twelve global countries including USA, Japan, UK, Germany and France, earned lower incomes, since 2019, in all income classes. At the same time 10 persons amongst the richest ones added to their properties \$319b in 2020 (Bloomberg) (of which: Tesla-Facebook-MicrosoftAmazon).

The Oxfam ${ }^{11}$ organization, moreover, argued that 1000 people in the world saw their wealth to reach record-levels, within 9 months, in 2020-1. The new poor needed 10 years to reach their previous status! The astonishing fact for USA was that when their administration decided to help citizens by posting cheques to them, it found-out that $1 \mathrm{~m}$ persons-in-need had... no address: they were homeless! And 10m were jobless!

The above suggest, clearly, that the economic system favors certain, rather few, persons, and more so during a rare combination of a depression and a pandemic, proving to be inequitable (Menta et al., 2021)! The present USA administration (Finance Minister), moreover, mentioned that she is pre-occupied with the economic inequality, and with the fact that US society needs improvement...

\footnotetext{
${ }^{10}$ Economists see 2 types of economic inequality: wealth and income. "Income inequality" rose within countries over the last few decades. Income comes from: wages, shares, rents \& selling companies. "Wealth inequality" means a small group of people to own most of the valuable items like: houses, cars, financial assets, shares etc.

${ }^{11}$ In Columbia Univ. they found that poverty increased by $~ 17 \%$ in USA; In Notre Dame and Chicago Universities they found also $6 \mathrm{~m}$ new poor in USA.
} 


\subsection{Evidence in Keynes (1936)}

What we wrote above is, regrettably, not written for the first time, not even recently, as Keynes (p. 272) wrote about "these outstanding faults of economic society" (Graph 1) in his last chapter in his famous "general" theory!

As shown, Keynes stressed 3 serious faults committed by the society he lived in: Unemployment, inequitable distribution of Income and Wealth. Graph 1, is thus, inspired by Keynes last chapter 24 in General Theory titled: "final comments for the social philosophy towards which the General Theory tends". Keynes was referring to his society he used to live, but the same problems has remained since then... Keynes mentioned the failure of his society to provide full employment, and the unequal distribution of both wealth and incomes. The inequality in wealth and incomes revived more decisive by the occasion of the Pandemic, and we saw the new rich people to become richer and the new poor to become poorer. As in time of Keynes also in our time taxation emerged as a corrective mechanism... Apart from income or profit taxation, an important issue is the inheritance tax concerning wealth. Should this tax be heavier? The further elaboration of these issues gets out of our aims.

Keynes was primarily concerned with the impact of saving on capital. Also, with the saving of the rich.

Does equity, by the way, mean that women are entitled to equal pay for equivalent work?

\subsection{People's Objective: To Exploit the Economy}

Our experience is that economic knowledge among people is used for the "exploitation of the economic system" ... We will give a few examples: 1) The law of supply tells us that if a good is produced in a quantity above what is demanded, its price will fall. 2) Originally, working women were less than working men; when the trend established so that where there are 2 employees, 1 of them to be a woman, (e.g., in USA), wages halved ... as the supply of labor doubled! Women liked it for they obtained economic independence... 3) The "willingness to pay" is estimated by the personal demand curve. This means that a firm finds-out what one is prepared to pay so that to obtain what he/she wants, instead of going-away empty handed. But this price may be higher than cost.

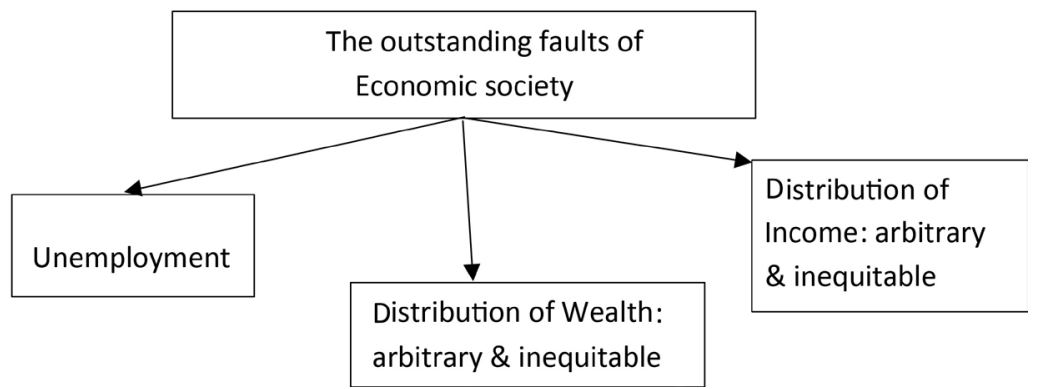

Graph 1. The outstanding faults of Economic society. Source: Inspired from Keynes (1936, Chapter 24). 
We will not discuss unemployment because we have no hope for this to be ever eliminated... Societies will produce new poor at all times. Countries, at the moment, rely mainly, for poverty on philanthropists, Church, donors ${ }^{12}$, volunteers, etc.

\subsection{Return to Keynes}

Returning to Keynes, a low propensity to consume-at full employment-will help capital to grow. Capital produces products for consumption, and thus a proper consumption level is also needed, meaning that the consumers should absorb all of what is produced ${ }^{13}$. Consumption has to free resources, willingly, for investment to be carried-out, meaning to "permit" saving. Depreciation is companies' saving, which has also to be spent in line with investment in new equipment. Keynes accused the un-spent depreciation for the 1929-1933 slump in USA!

Falling consumption, thanks God, needs not an economic law, but a psychological one! For Keynes, saving made by institutions, and sinking funds, (=depreciation), can be considered adequate ${ }^{14}$ for investment, and a redistribution of income, if it increases the propensity to consume, will favor the growth of capital (p. 373).

Keynes saw that an economy is composed by two dominant and separate actors: the class of investors and the class of consumers (including users). The sector of services developed by leaps and bounds in our times as these are related to the quality of life.

As Keynes (1936: p. 96) wrote:

$$
0<\mathrm{d} C / \mathrm{d} t: \mathrm{d} Y_{t-1} / \mathrm{d} t<1,
$$

meaning that both income $\left(Y_{t-1}\right)$ and consumption $\left(C_{t}\right)$ increase, but

$$
\mathrm{d} C_{t} / \mathrm{d} t<\mathrm{d} Y_{t-1} / \mathrm{d} t
$$

(the fundamental psychological law) (Goulielmos, 2018b). This law permits increasing saving; investment entitles people to a higher income:

$$
\begin{aligned}
& Y_{t+1}=C_{t}+I_{t+1}, \\
& S_{t}=Y_{t+1}-C_{t},
\end{aligned}
$$

and

$$
S_{t}=I_{t+1}
$$

\footnotetext{
${ }^{12}$ Ardmore Shipping, ISWAN and others, responded to help crews subject to the new pandemical wave in the sub-continent. We saw the trend of donations to get stronger nowadays, and this was fueled by companies' profits, especially in shipping industry.

${ }^{13}$ Keynes innovated by focusing on the impact that the stock of unsold produced goods has on employment. Keynes always cared about employment first of all. So, the line of thought of Keynes was to absorb the entire production of consumers goods; to devote to consumption less and less \% of current income; to provide resources unused in consumption for investment equal to saving and produce a higher income each time, and higher saving, and so on.

${ }^{14}$ The Greek GDP was $€ 163 \mathrm{~b}$ ( $\$ 189 \mathrm{~b}$ ) in 2020 . The quarter real GDP was $€ 42 \mathrm{~b}$ and saving was $27 \%$ of it or $€ 11 \mathrm{~b}$. Real Gross fixed capital formation was close to $€ 5 \mathrm{~b}$. Thus Saving $€ 11 \mathrm{~b}>$ Investment $5 \mathrm{~b}$, leading to unemployment.
} 
where $I_{t+1}$ stands for investment and $S_{t}$ for Saving (Keynes, 1936: p. 63).

\subsection{This Would Be a Better World If Avoided}

Economics had to avoid theories advanced by social scientists, we believe, like Bentham ${ }^{15} \mathrm{~J}$ (1748-1832), based on the "principle of greatest happiness"; or authors of "hedonism's philosophy", based on only pleasure-seeking; or like Greek Epicurean ${ }^{16}$ philosophy (c. 300 BC) shouting: "eat, drink, tomorrow we die". Or Marx (1818-1883), denying the free will; or $\operatorname{Darwin}^{17}$ (1809-1882), descaling humans down to Apes! In other words, to treat humans not as consisting only of body.

Economics focuses exclusively on human passions ${ }^{18}$, by requiring "maximization of personal satisfaction" (welfare; happiness), something unattainable and utopian. The great excuse of positive economics is that it does not deal with what we have to do, but of what we did!

\subsection{Reverting to Keynes}

Keynes was the economist who got in grips with real problems, mainly in, or round, 1936, following Marshall, his teacher. Keynes could not do differently, as he lived in 1929, and thereafter, when the first global economic depression occurred. He saw that the human economic system had serious defects and perhaps Marx ${ }^{19} \mathrm{~K}$ was right in saying that Capitalism creates crises. Keynes' contribution was, however, also theoretical, as he corrected the macroeconomic theory of the classics. We believe that if economists paid attention to rectify the present human economic system, the system could be fairer.

\subsection{Further Paradoxes}

Returning to the main paradoxes of economics, we all know about the so-called "law of demand". This says that if a good is overproduced, out of the control of the producer, then excess-production has to be destroyed...to prevent a fall, or achieve a rise, in price. Instead of giving it to the new poor who could not buy anything anyway...?

Also, we all know about the "homogeneity" property of goods and services, which one cannot price them higher as being the same (0P2) (Graph 2). Firms, however, succeeded in making their products and services to look different in the eyes of the buyers, and charge a higher price (0P1)! In this endeavor, Advertising and Marketing helped decisively, by the so called 5, or so Ps, and so they gained their status among business sciences!

As shown, a homogeneous product is sold at $0 \mathrm{P} 2$. This is the case of a competitive equilibrium $(\mathrm{MC}=\mathrm{MR})$. The same product, when presented as different,

\footnotetext{
${ }^{15}$ English utilitarian, philosopher etc., arguing that the end of life is happiness i.e., pleasure!

${ }^{16}$ Epicurus was an Athenian philosopher who held that pleasure is the highest good.

${ }^{17}$ English naturalist and author of the origin of species by means of natural selection (in 1859).

${ }^{18}$ Par excellence this is the focus of Advertising and Marketing.

${ }^{19}$ In his "Das Kapital", in 1867, argued that labor class becomes miserable.
} 


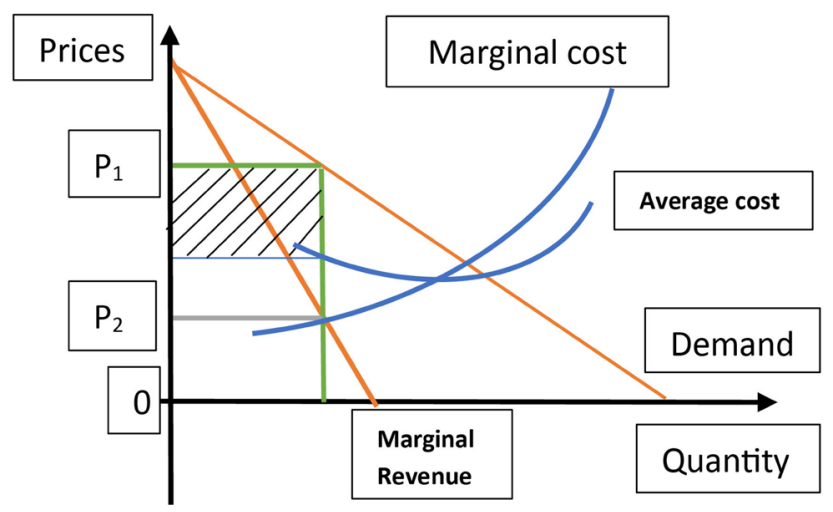

Graph 2. Pricing a non-homogeneous product. Source: author.

is sold at $0 \mathrm{P} 1$ ( $\mathrm{MR}=\mathrm{MC}$ again), characterizing the equilibrium of a monopoly (or an imperfect market like the "monopolistic competition"; not shown)! The firm achieves the so called super normal profits (shadow area). Without dis-homogeneity, which is based on an utopia, this could be not possible ${ }^{20}$.

Shipping companies also try to show unlike: they print well designed prospectuses mentioning unbelievable records of safety, quality, reliability, etc. In their internet sites they do the same. They try to build an image, but charterers... do not pay a higher freight rate... as they consider these services ... homogeneous! Age related to accidents, however, made them unlike!

Another important psychological law is when one holds a lot of goods, including money (as a store of value), the less (Graph 3) valuable considers them ${ }^{21}$ !

As shown by Graph 3, as the quantity of the available money, or of a good, increases from $\mathrm{OA}$ to $\mathrm{OC}$, so the value of it to its owner falls. The increase is due to the increased supply, one cause of which may be a pandemic. The value or validity to the owner falls from a high level to a low one. This excludes cases of stinginess. We think this to be a common experience. Thus, more easily abundant money etc. is given-away in the form of charity, donation or even higher taxation (e.g., Gates B stated he was ready to pay more taxes). I may call this the "New rich phenomenon", meaning that as income pours-in, it does matter to pay more taxes. We $\mathrm{knew}^{22}$ already, that a $€ 1000$ tax to a rich man, does not mean the same thing to a poor one... (this is the basis of the progressive taxation: the more you earn, the more you pay).

\footnotetext{
${ }^{20}$ The number of products and services that are made to look different, in the eyes of buyers, is already high. Let one wanted to buy a pack of a particular brand of tea. One will find-out 12 manufacturers, but all at different prices... Same raw material! How many times one bought a bottle of whisky - made out of the same ingredients, but shown as different product, at a higher price? Believing that one will attract a beautiful woman, as shown on TV, stepping-down from the first-floor bedroom... Certain whisky brands claim to be different by using water from the passing near-by river! How many manufacturers produce products placing their title etc. at easily observable places on them, and as one is wearing them, he/she claims ... being different? This is a passion: to be, to show-off, to feel, and to act, as somebody very unlike from the mass!

${ }^{21}$ Imagine the value of a bottle of water in desert vis-à-vis in a mini market...

${ }^{22}$ Jesus Christ praised the poor widow who put in the Jerusalem temple of Solomon's treasury, say $€ 2$. This amount was all her property...
} 


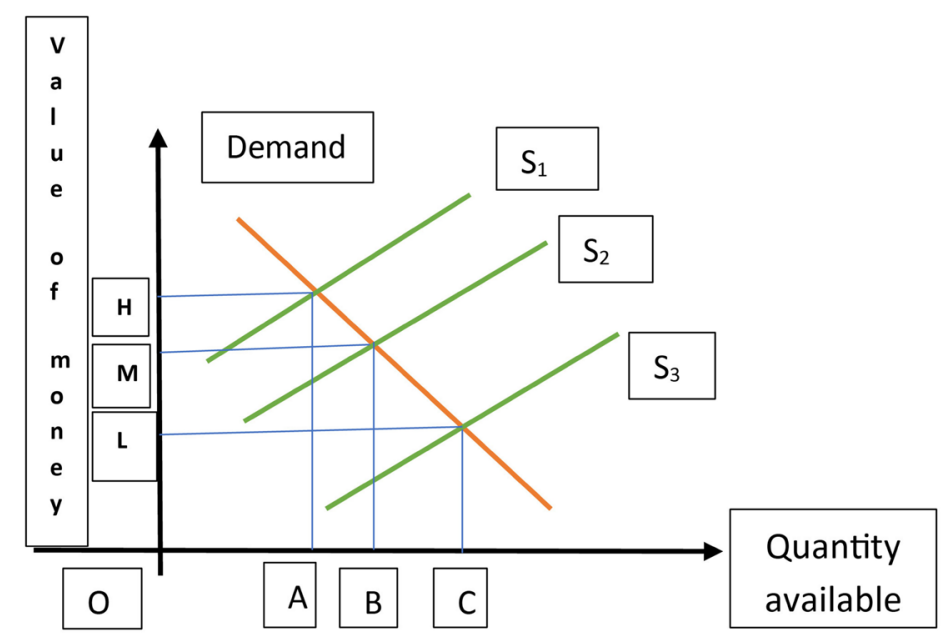

Graph 3. The "New Rich Phenomenon”. Source: author.

\section{The Economic and Shipping Vintage Models}

"Vintage models" are those that represent the impact of age on capital, and its productivity etc. Capital goods are expected to become less productive, as their age increases!

Vintage models appeared in the literature (1959-1965) in connection with ${ }^{23}$ growth models, where their authors realized that capital, and its embodied technical progress, age with time.

The vintage factor considered par excellence important, because only new investment can bring innovation. Pioneers in this field was Salter W.E.G. (his 1955 doctoral thesis) in UK for economics and Goulielmos A.M. for shipping economics (1974's doctoral thesis in Brunel University). Vintage models appeared also in Norway by Johansen $(1959 ; 1961)$.

Ship management we believe can provide insights into the vintage models as shipping is a par excellence a "vintage capital industry", being also a reason to write this work. Salter (1969) argued that the substitution possibilities-between labor and capital-should be confined only to ex-ante investment decisions. But this is not true for shipping!

A vessel can be made longer, faster ${ }^{24}$ (installing new engines; new propeller), with more powerful cranes (installing new cranes), and the relationship between Capital and Labor can also change by law ${ }^{25}$. E.g., a cheaper crew is signed-on allowed by legislation in the name of automation. Thus, productivity of both labor and capital can be increased, but even so, it is the technical progress which allows this to occur in ships. A new chapter exists dealing with the various automations.

Notable is that in the advanced industrial countries, where shipbuilding is lo-

${ }^{23}$ Also, education, knowledge, as well experience, embodied also in humans, age also with time, as all we know by now! Passing time reduces human value.

${ }^{24} \mathrm{~A}$ literature exists titled: "ship performance" (Hughes, 1996).

${ }^{25}$ One must not underestimate the role of what we will call "legal obsolescence", like e.g., in the case of "double hulls". 
cated, the national crew is becoming more and more expensive or rarer (USA; Japan; UK) due to rising living standards, and thus a reduction in labor quantity (numbers) has to be expected from technology ${ }^{26}$. Technology responds to economic challenges, e.g., when oil price drastically increased, new fuel-saving engines for ships produced. This is the "induced technical change".

As a result, the latest "best practice techniques" in ships can be manifested theoretically by a falling set of the relevant isoquants towards less labor quantity, as follows (Graph 4).

As shown, the reductions in crew numbers for a vessel of increasing size is combined with increases in capital quantity, due to a number of labor-saving techniques or economies of scale. We do not consider easier to have reductions in both crew numbers and capital quantity in the short run, though desira$\mathrm{ble}^{27,28}$. Moreover, main engines were made smaller, needing less space (allowing for more cargo) and consuming less fuel in the 1970s; speed, generally, increased all along ${ }^{29}$.

If the reduction in input quantities is substantial, then all smaller vintages, (of newer technology), would be more competitive, and given demand, they would phase-out all older ships. But this does not happen in shipping. Our experience has taught us that each vintage ${ }^{30}$ has its own rewards depending on its individual supply and demand.

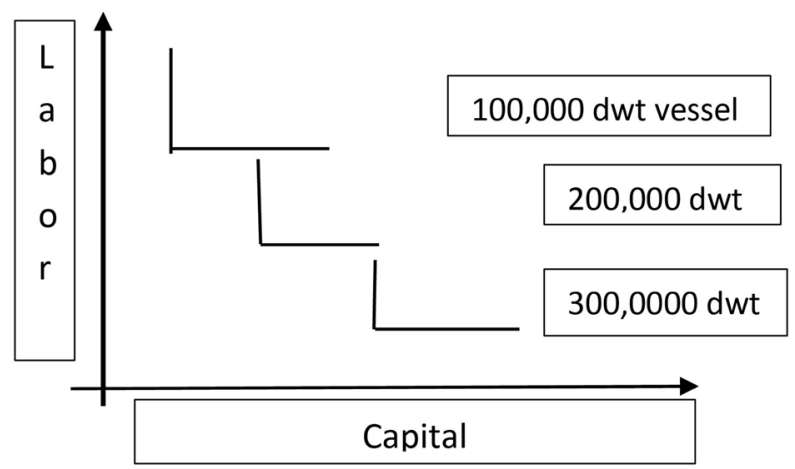

Graph 4. Three isoquants of 3 different ships with falling labor requirements. Source: author.

\footnotetext{
${ }^{26}$ It is remarkable for one to see the reduction in ship labor over the centuries from 56 persons to 15 per ship!

${ }^{27}$ Worth noting is that in the past, sails and wood were replaced by iron (plus rivets) and steam, and these replaced by steel and oil (Diesel engines in 1940s), and steel replaced by thinner steel (Japan 1970 s). Thus, shipping technical progress is a long-term phenomenon, and is really fascinating. In Greece the first 3 steam ships obtained 50 years after (in 1856) other shipping industries, while UK was first in steamers (in 1802), followed by USA (in 1807). In 1870 steamers held $16 \%$ of all tons and by 1910 this increased to $75 \%$ worldwide.

${ }^{28} \mathrm{~A}$ sailing ship from Odessa to London needed 2 months, while a steamer needed 20 days! The steam engines received 5 improvements between 1830 and 1880 .

${ }^{29}$ The increase in speed is heavily restricted by fuel consumption and oil price.

${ }^{30}$ Ships should not be grouped e.g., in tankers or dry cargoes. A Ships is a distinct personality having size, age, speed, maintenance record, cargo capacity, accident history, dry-docking history, own cranes, embodied technical change, and more important their own trades and routes, distances and thus a personal demand and supply!
} 
A businessman will choose those techniques, which minimize costs, and maximize profits... (Harcourt \& Laing, 1971: p. 15). The first is manageable, the $2^{\text {nd }}$ is impossible in shipping. Vintage machines (and ships) are kept in use as long as they continue to earn positive quasi-rents and are scrapped if these are zero. In shipping, however, we know that a shut-out decision it may take 3 years, and also scrapping is a source of substantial income from scrap-iron due to economies of scale.

We saw that technical progress, and thus lower vintages of capital, are more productive if they succeed to lower both capital cost and operational one! This involves quantities and prices.

\section{A Microeconomic Shipping Vintage Model}

\subsection{A Case-Study}

Suppose we are given-over the management of a shipping company owning 20 ships.

1) Background: a) Company's accountants informed $u s^{31}$ that the book value of company's fixed capital (ships) is almost $\$ 247 \mathrm{~m}$. b) A fixed cost of $4 \%$ p.a. for depreciation $^{32}$, on equal yearly installments, over 25 years, equals $\$ 9.9 \mathrm{~m}$ p.a. c) A $5 \%$ p.a. profit/interest on book value, over a span of 20 years, $(\$ 12.3 \mathrm{~m}$ p.a.) is desirable. d) The cost to operate the 20 ships is equal to $\$ 31.5 \mathrm{~m}$ p.a. Thus, the company had a total cost of almost $\$ 54 \mathrm{~m}$ p.a. (\$7397.3/day) and e) Freight market is in depression paying $1.6 \mathrm{~m}$ per ship p.a. (\$4614.3/day). So, $1 / 2$ of the ships should be laid-up!

2) Preliminary conclusion: a difficult task because of the high total fixed cost of $\$ 22.2 \mathrm{~m}$ p.a.!

3) Vintage characteristic: Company's ship ages differ one from the other by 1 year. Age adds on every ship an additional cost of operation of $\$ 50,000$ p.a. (for every 2 years). The youngest one, (1 year of age), is the most "efficient" operationally, spending only $\$ 1.1 \mathrm{~m}$ p.a. But she is the most expensive having $\$ 1.8 \mathrm{~m}$ p.a. fixed cost ( $\$ 800,000$ for depreciation and $1 \mathrm{~m}$ for profit) (a total of $\$ 2.90 \mathrm{~m}$ p.a.). The oldest one (number 20 ) has $\$ 2.05 \mathrm{~m}$ p.a. for operations plus $\$ 0.14 \mathrm{~m}$ p.a. for yield and $\$ 0.18 \mathrm{~m}$ p.a. depreciation (a total of $\$ 2.37 \mathrm{~m}$ p.a.).

4) Stopford assumed that the lower vintages ( 1 - 10) should be employed. The ships, however, 11 - 20, having a rather higher operation cost and a lower depreciation/interest cost (Table 2) (in accordance with Keynes) may be more profitable. To show this we constructed Table 2.

\footnotetext{
${ }^{31} \mathrm{~A}$ closer estimation of the value of capital like ships in the market can be prepared by specialized houses-valuers, but at a fee of a few thousand \$. Below we propose an inexpensive statistical method.

${ }^{32}$ Capital cost is related to the price at which the ship bought (or built). Depreciation gets from gross profits to establish company's saving, towards buying another ship at the end of her (technical or economic, whatever comes first) life. To do this, however, profits-before depreciation-must exist! Moreover, if the ship is a new building, capital cost arrives at $50 \%$ of total! This means that the company having a lower capital cost due to buying used ships, instead of new, and at rock bottom prices, and as result having a lower depreciation for the same reason, is more competitive. A used ship may be valued at $1 / 5$ of the value of her newly built sister!
} 
Table 2. The fleet and the fixed \& variable costs, plus freight rate, expected yield and profit.

\begin{tabular}{|c|c|c|c|c|c|c|}
\hline Vessel's age & $\begin{array}{c}\text { Operations Cos } \\
\text { p.a.m } \$\end{array}$ & $\begin{array}{l}\text { eld expected } \\
\text { p.a. } \$ \$\end{array}$ & $\begin{array}{l}\text { Depreciation } \\
\text { m\$p.a. }\end{array}$ & $\begin{array}{c}\text { Total cost } \\
\text { p.a. m \$ }\end{array}$ & $\begin{array}{c}\text { Revenue } \\
\text { p.a.m\$ }\end{array}$ & $\begin{array}{l}\text { Profit/Loss } \\
\text { p.a.m } \$\end{array}$ \\
\hline 1 & 1.10 & 1.00 & 0.80 & 2.90 & 1.60 & -1.30 \\
\hline 2 & 1.15 & 0.96 & 0.77 & 2.88 & 1.60 & -1.28 \\
\hline 3 & 1.20 & 0.92 & 0.74 & 2.86 & 1.60 & -1.26 \\
\hline 4 & 1.25 & 0.88 & 0.70 & 2.83 & 1.60 & -1.23 \\
\hline 5 & 1.30 & 0.84 & 0.67 & 2.81 & 1.60 & -1.21 \\
\hline 6 & 1.35 & 0.80 & 0.64 & 2.80 & 1.60 & -1.19 \\
\hline 7 & 1.40 & 0.76 & 0.61 & 2.77 & 1.60 & -1.17 \\
\hline 8 & 1.45 & 0.72 & 0.58 & 2.75 & 1.60 & -1.15 \\
\hline 9 & 1.50 & 0.68 & 0.54 & 2.72 & 1.60 & -1.12 \\
\hline $\begin{array}{c}10 \text { low } \\
\text { vintages }\end{array}$ & 1.55 & 0.64 & 0.51 & 2.70 & 1.60 & $\begin{array}{c}-1.10 \\
\text { total } \$ 12.01 \mathrm{~m}\end{array}$ \\
\hline 11 & 1.60 & 0.60 & 0.48 & 2.68 & 1.60 & -1.08 \\
\hline 12 & 1.65 & 0.56 & 0.45 & 2.66 & 1.60 & -1.06 \\
\hline 13 & 1.70 & 0.52 & 0.42 & 2.64 & 1.60 & -1.04 \\
\hline 14 & 1.75 & 0.48 & 0.38 & 2.61 & 1.60 & -1.01 \\
\hline 15 & 1.80 & 0.44 & 0.35 & 2.59 & 1.60 & -1.00 \\
\hline 16 & 1.85 & 0.40 & 0.32 & 2.57 & 1.60 & -0.97 \\
\hline 17 & 1.90 & 0.36 & 0.29 & 2.55 & 1.60 & -0.95 \\
\hline 18 & 1.95 & 0.32 & 0.26 & 2.53 & 1.60 & -0.93 \\
\hline 19 & 2.00 & 0.28 & 0.22 & 2.50 & 1.60 & -0.904 \\
\hline $\begin{array}{l}20 \text { higher } \\
\text { vintages }\end{array}$ & 2.05 & 0.18 & 0.14 & 2.37 & 1.60 & $\begin{array}{c}-0.77 \\
\text { Total for } 10 \\
\text { ships } \$ 9.702 \mathrm{~m}\end{array}$ \\
\hline
\end{tabular}

Source: author.

As shown, the company can save $\$ 2.31 \mathrm{~m}$ p.a. (12.01 m minus $9.70 \mathrm{~m}$ ) by... employing the 10 older ships! As shown (Figure 1), the "book value" is a dominant (fixed, fast rising) cost element, and as fleet's age falls, this cost increases! In fact, in order to show in the same figure, the impact of the ships' book value, and thus of depreciation etc., we presented ships' age starting from older to younger ships, while the impact of the operating cost showed from younger to older. Apart from this, the figure wants to show the smooth and moderate increase in ships' operating cost with reference to age and the detrimental increase in ships' book value and depreciation etc. expenses.

Further, the fixed cost can be reduced if ships, which were bought dear, are replaced by cheaper ones! But this cannot be done in the short-run according to microeconomic theory, but in shipping this is possible! If do that the required yield will also be reduced as the book value will fall. The Greek rule is: "buy at rock bottom prices. Then sell". 


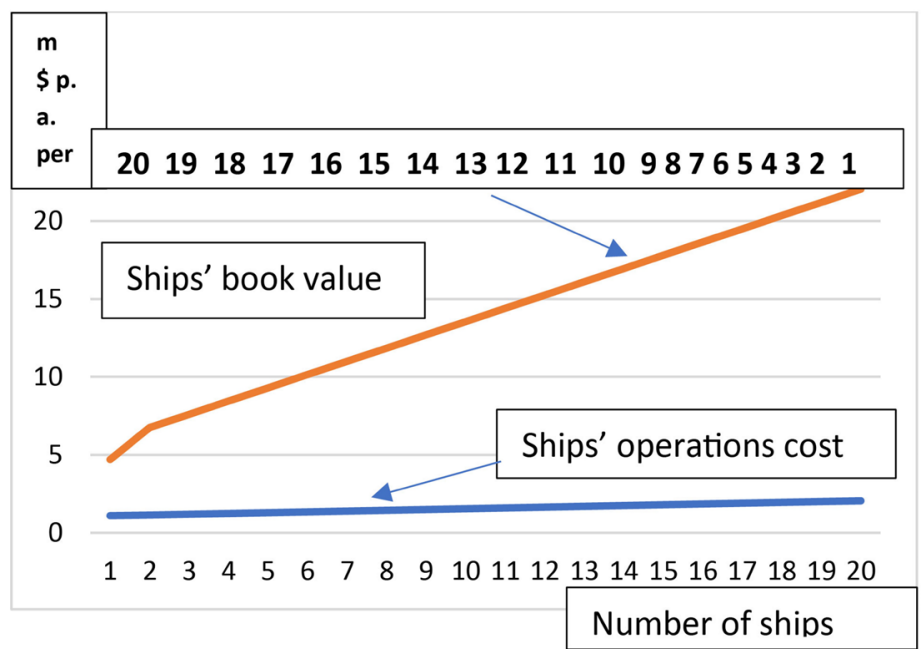

Figure 1. The Book value and Operations cost for the case study. Source: Author; data from Stopford (2009).

After managing fixed cost, we had to care about reducing operational cost. Greeks repeatedly applied reductions in crew wages by $20 \%$ in a crisis. A provisional solution is to lay-unprofitable ships-up; and an ultimate one is to scrap them! But a pre-drastic solution is when one buys/build ships! We come to this issue now.

\subsection{The Impact of the Purchasing or Building Price}

As shown in Figure 2, the value of capital (tankers), varied over the years 1980-1992, reaching a low in Feb. 1986 of \$35m vis-à-vis \$95 (high) in Jan. 1992 (VLCC). Thus, the perfect timing in building a capital, may reduce capital cost by $63 \%$ ! Therefore, it is not only the "embodied technical progress" that matters, but also the "embodied perfect timing" (our term). Businessmen as a result have to choose not only those techniques that will minimize costs and provide expectations of maximum profits, but also an embodied perfect timing (Goulielmos, 2021).

Figure 3 demonstrates the comparative advantage between the owner who prefers $2^{\text {nd }}$ hand ships, on the basis of their price, instead of newly built.

As shown, there is a steady difference between the prices of the 2 vintages of the same capital, (sisters), varying from $\$ 5 \mathrm{~m}$ to $\$ 15 \mathrm{~m}$ (1976-1992). The opportunities for an embodied perfect timing are apparent, given a maximum $\$ 23 \mathrm{~m}$ difference in the vintage price of the same capital good over time! For economy, and for the industry, the substantial fall in the price of capital, due to: 1) lower age and 2) a perfect timing, is enjoyed by the last buyer, while the first owner pays the full price!

\subsection{Data and the Relevant Curves-The Case Study}

Our data are provided by Stopford (2009: p. 331). We re-arranged them, however, so that to derive curves closer to microeconomic theory. In Figure 4, we 


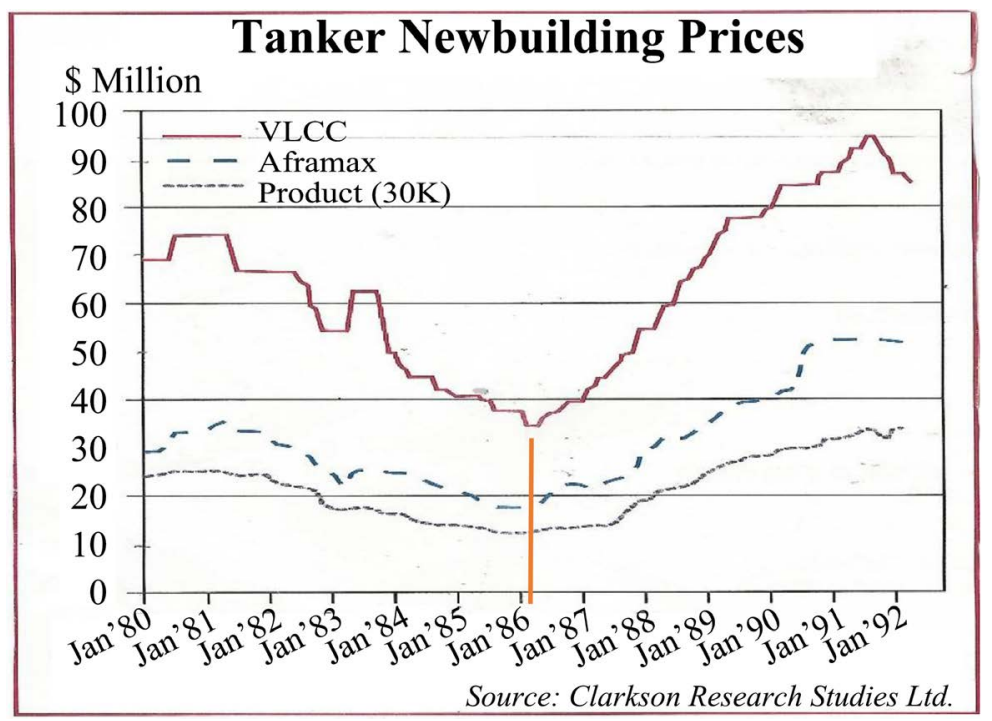

Figure 2. The prices of newly-built capital goods (tankers), 1980-1992.

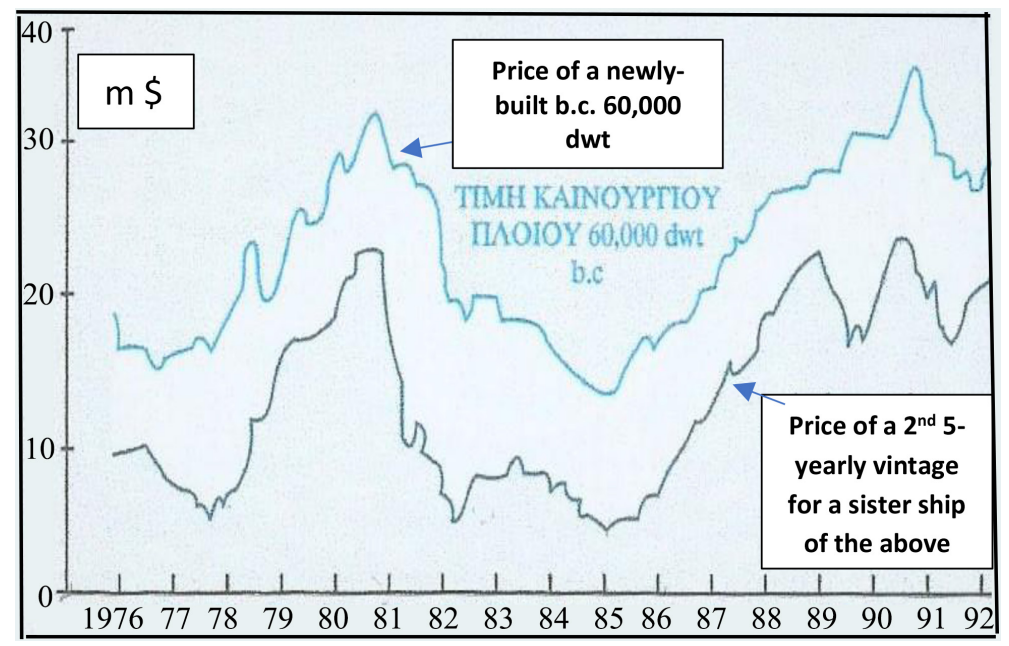

Figure 3. The price of a new-building bulk carrier of 60,000 dwt and her sister, 5 years older, 1976-1992. Source: Author.

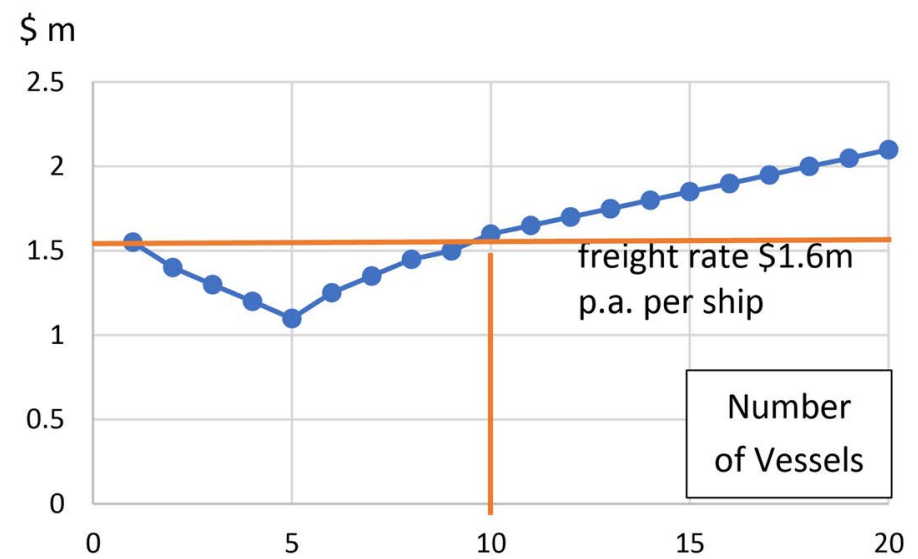

Figure 4. The Marginal cost curve of a shipping company (case-study). Source: data from Stopford (p. 331). 
re-arranged the ships, and their marginal costs, so that to derive a U-shaped curve, as far as possible.

Important is that the short run-in shipping is really very short, $1-3$ months. This is the time required to sell/buy a ship, and thus change company's capital! A shipping company, therefore, is always in the long run! The long run for the industry, however, is on average 2 years, and equals the time needed to construct a newly-built ship... This is a case where industry and its firms have different long runs!

The freight rate must be equal to $\$ 2.1 \mathrm{~m}$ p.a. (=MC20) for the whole fleet to be employed! The actual "marginal revenue" p.a., however, was $\$ 1.6 \mathrm{~m}$ p.a. (MC1-10 $\leq \mathrm{MR})$.

In Figure 5, we formed equilibrium with every ship, where MC1-3 = MR $(=\mathrm{Pc})$.

The above 3 ships produce the required ton miles to satisfy the given demand OQc, based on their efficiency (MC1-3). We added (not shown) one voyage at a time and this is a more realistic ${ }^{33}$ than to add one ship at a time (Stopford). A vessel will not transport cargo (undertake a voyage) at a loss $(<\mathrm{AVC})$ !

\subsection{Economies of Scale}

As shown in Figure 6, AC is falling, as the number of ships increases.

The number of ships indicates the size of a shipping company. In the above model we have no information about the size of each vessel. We assume, however, that as the age of a ship falls, her size increases, due to economies of scale andlor due to company's policy.

The AC curve presented together with that of Marginal Cost, tells us about the potential total loss suffered by this company due to the fact that $\mathrm{AC}<\mathrm{MC}$ (Graph 5) due to economies of scale!!

As shown, the equality of AC with $\mathrm{MC}$ is not possible due to the high fixed cost ( $\$ 22.2 \mathrm{~m}$ p.a.). The company, however, can equalize MC with AVC (at the $10^{\text {th }}$ ship inclusive) (Figure 7), and so to ... lay-up $1 / 2$ of its fleet!

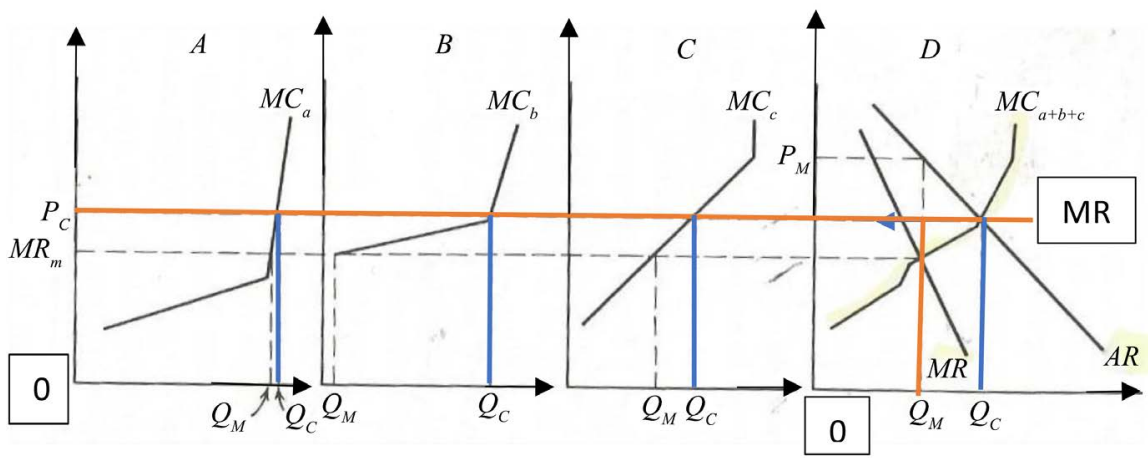

Figure 5. Equilibrium with 3 ships of a shipping company. Source: author.

\footnotetext{
${ }^{33}$ Companies in shipping prepare the "voyage estimated result" form, and then the manager undertakes a voyage, if a pre-calculated net profit exists per day in time charter equivalent. In this form freight revenue per dwt, and in total, is shown, less brokers' commission. The voyage's expected days at sea and in ports, port and canal dues, bunkers tons in fuel and diesel and their prices, and taxes on freight if any. Then this is compared with operational cost.
} 


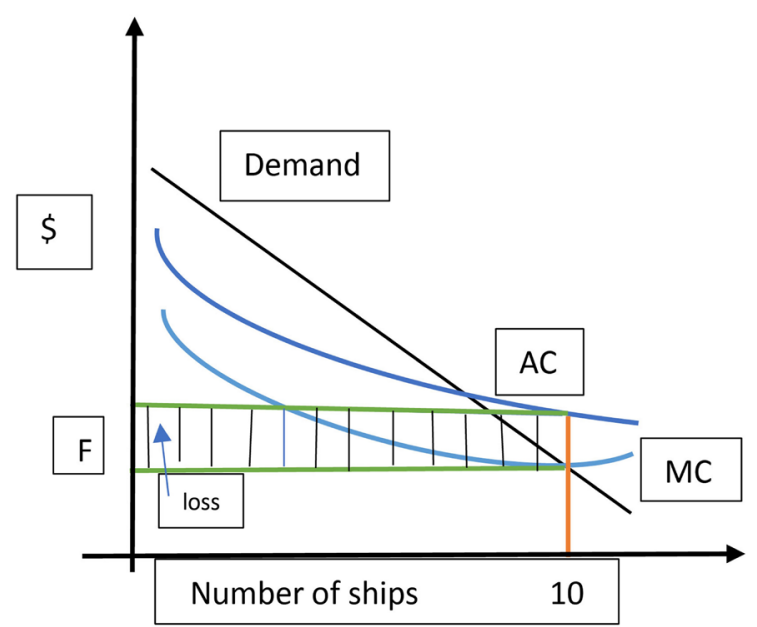

Graph 5. Economies of scale where $\mathrm{MC}<\mathrm{AC}$.

\section{$\$ \mathrm{~m}$}

30

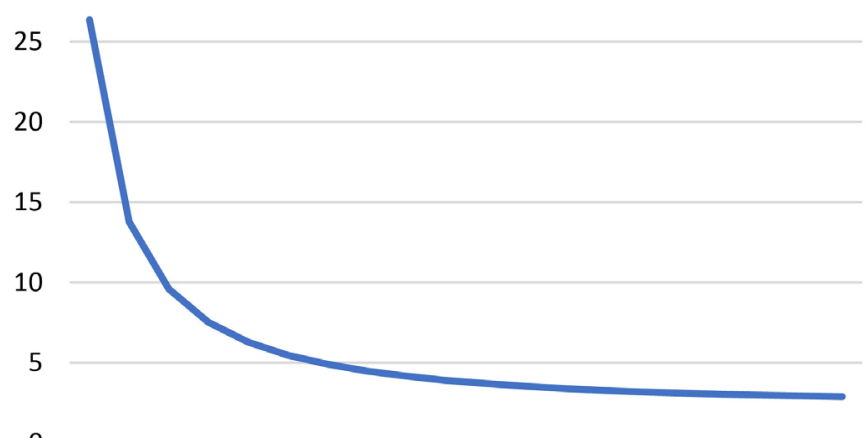

0

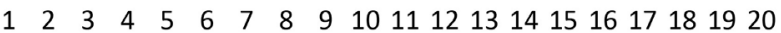
Number of ships

Figure 6. Company’s Average Cost per ship (economies of scale). Source: Stopford's model.

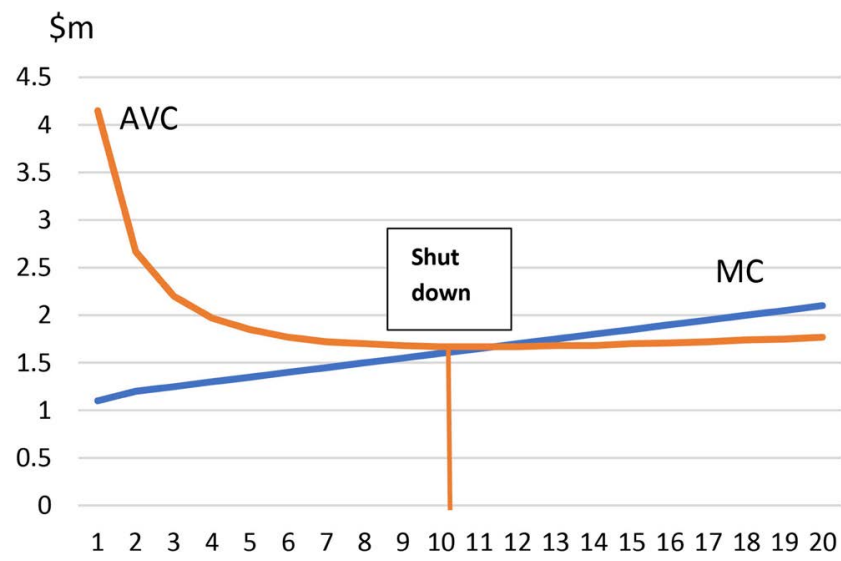

Number of ships

Figure 7. Firm's AVC and MC p.a. Source: author, data from Stopford (2009). 
The marginal cost is defined as the cost added to the total cost due to one extra unit of production. But for a ship, one additional unit of production is one extra voyage.

We come next to an important part of a company's fixed cost: depreciation.

\section{A Depreciation Strategy}

Depreciation is company's accounting practice to recoup, gradually, from gross profits, the greater part of total $\operatorname{cost}^{34}$, (price), paid for buying/building a tangible fixed asset-tfa (a ship). This is company's expense (Reid \& Myddelton, 2005: p. 142). The depreciation amount is reduced by scrap, or sale, money, obtained at the end of $t$ a's useful life, or even before ${ }^{35}$ (in shipping). Shipping companies practice the "asset play ${ }^{36 "}$, providing profits directly to shareholders.

Depreciation in installments, we believe, is rational, as a $t f a$ is used for more than 1 year $^{37}$. Also, a company's life is longer-about 100 years-than a tfa's life, which is 20 years. Without a tfa production is not possible. A number of causes for depreciation is: the passing of time; wear and tear; technical obsolescence; legal obsolescence; a marine accident; laying-up/restarting and a market obsolescence.

We gathered into our discussion, so far, 4 uncertain factors in relation to depreciation: 1) the years during which a $t$ fa will be in a useful life, 2) its value at its end, 3) the price of its replacement and 4) gross profits!

Depreciation is therefore a fund, built, by a profitable company, to be able to "produce" forever... an elixir. This means... a way to replace also economy's capital. This shows how important depreciation is for economy ${ }^{38}$, as it consists of the greater part of economy's saving!

Important for shipping is that a $t$ 'a's resale, or scrap price, may be $\geq$ or $<$ than its book value, creating a loss, a profit or nothing! This, if it is a capital gain, we believe, it had to be written to a "reserve", than paid to shareholders.

Depreciation has to be carried-out in a systematic way in every accounting period, as determined by national and international accounting standards-IAS. Depreciation is:

$$
\mathrm{D} \$ \text { p.a. }=\mathrm{OP} \$ / \mathrm{UL} \text { in years }-\mathrm{SV} \$ \text { or }-\mathrm{RV} \$ \text {, }
$$

where RV\$ stands for re-sale value and SV\$ for scrap one. Depreciation is positive if there are gross profits. Depreciation wrongly, we believe, increases com${ }^{34}$ Including expenses for improvement, interest on finance during construction, related legal expenses, installation costs etc.

${ }^{35}$ In non-shipping industries, the sale of a $t f a$, before its useful life ends, is not in the mind of managers, but of shipowners!

${ }^{36}$ This means to buy, or even build, a ship in a "perfect timing" with a purpose to sell her at a higher price sometimes in future in "perfect timing" too.

${ }^{37}$ In shipping also other expenses, which cover more than one accounting period, are charged in more than one period, like: "drydocking expenses" and the "4-yearly surveys" expenses.

${ }^{38}$ Keynes (p. 100) attributed the 1929 slump, and thereafter, to depreciation etc. done during the previous 5 years in USA, and not spent! In 1928, in UK, 55\% of gross investment of 791m£ was for physical wear \& tear; in 1929 this was 60\%; in $193070.5 \%$ and in 1931 91\%. In USA, in 1929 \& 1927 , this was $26 \%$ on $\$ 34.5 \mathrm{~m}$; and $25 \%$ in $1925-6-7$; i.e., a four-year depreciation. 
pany's losses. When company's income is zero, depreciation had also to be zero...

A tfa's useful life, SV and RV, are 3 crucial unknowns in the above equation (10). Bankers estimate UL in a rather conservative way, for obvious reasons, when they provide finance. This may be 20 years for dry cargo ships and 15 years for tankers. Bankers are interested also in RV/SV, because they may need to sell the ship to get part of their loan in case of a default. Charterers are also interested in $t f$ 's $\mathrm{UL}$, as they believe that the shorter the vintage of a vessel, the less frequent she may cause a marine accident, especially for tankers! This is a serious obsolescence!

Summarizing, a depreciation strategy raises a number of important issues (Graph 6).

As shown, 13 factors determine depreciation, 3 of which are known: the level of depreciation determined by the original price (book value) of the ship, her estimated (productive) life, and the method of depreciation used. Worth noting is that the main underlying factor of depreciation's amount, is the price at which capital bought (or built)! The recommended strategy in shipping businesses is to "embody perfect timing", which greatly affects the price of a $t f a$, and thus depreciation (Goulielmos, 2021).

One may think it strange to relate depreciation to market conditions! But market conditions increase company's profits from capital, by extending capital $s$ life! E.g., the bulk carriers were, on average, scrapped ${ }^{39}$ at their 25.2 years (1995-2000: period of weak market) and the tankers at their 24.7 years. Conversely, in 2006 (year of high earnings) scrapping ages increased to 30 and 28 years respectively (Stopford, 2009: p. 239). Good markets provided almost 5 extra profitable years!

Very important, however, is the statistical relationship between the value of a ship and her age (Figure 8).

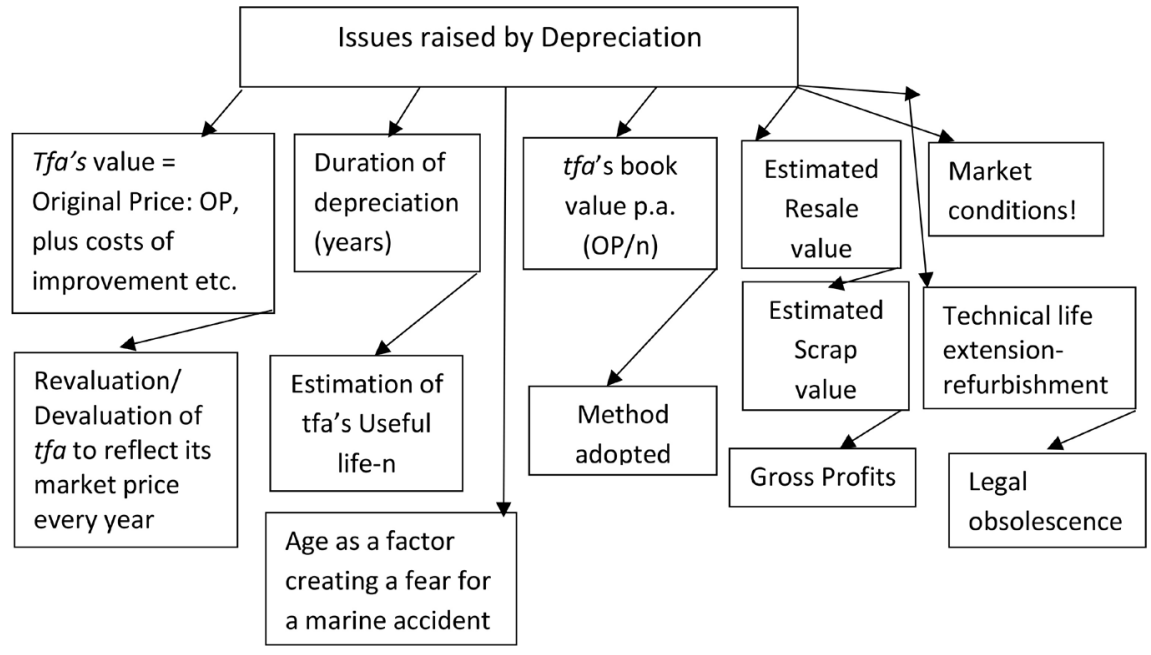

Graph 6. Issues raised by Depreciation. Source: author.

${ }^{39}$ Cruise ships scrapped at 43.8 years; livestock 33.9 ; passenger ferries 30 . 


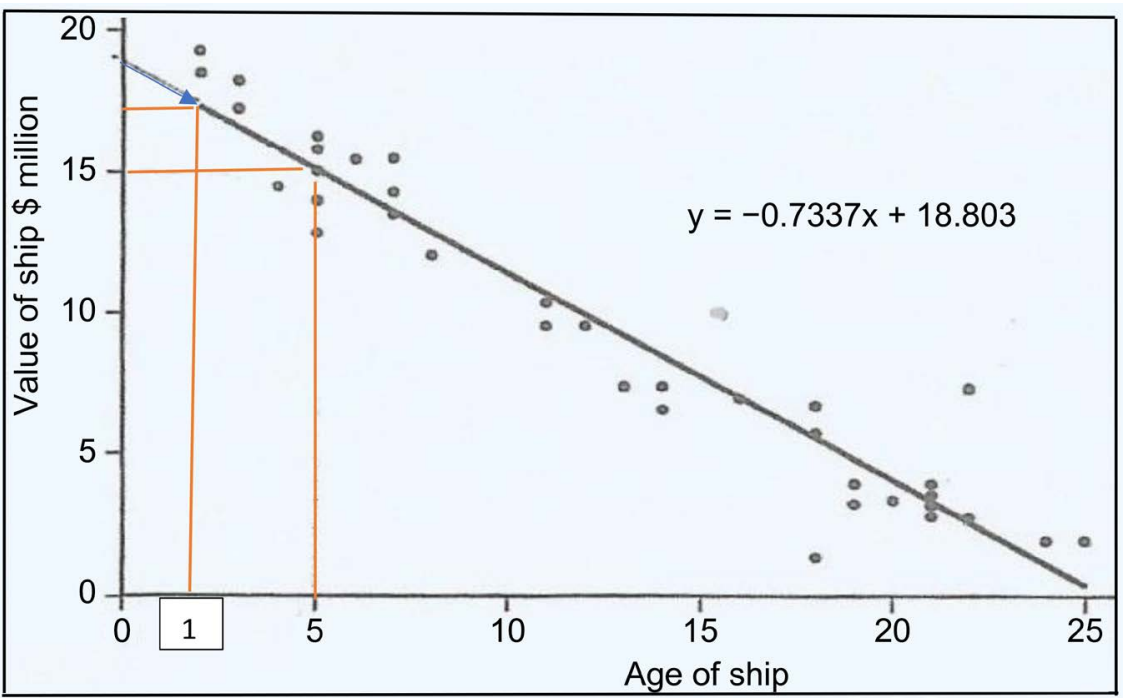

Figure 8. The relationship between the value of a ship (Panamax bulk carrier, sold in 2002) and her age. Source: Stopford (2009), p. 239, modified.

Using equation 11 we see that the value of a ship falls ${ }^{40}$ from $\sim \$ 18.8 \mathrm{~m}$ at her 0 year (delivery) to $\$ 1.19 \mathrm{~m}$ at her $24^{\text {th }}$ year-near the end of her life.

$$
Y=\text { ship's value }=-0.7337 x+18.803 \text {, }
$$

where $x=$ age in years, $n=36$ observations

We may find-out vessel's price at her first 5 years of age-the age preferred by Greek shipowners to buy ships-which is $\sim \$ 15.14 \mathrm{~m}$. The useful life is, statistically, determined at 25.63 years at zero-scrap value $(Y=0)$. A regression, as the above, may be used by companies to estimate the historical value of their existing ships, or the ones they want to buy!

This regression was based on data covering 9 months in 2002. Also, the regression tells us the ship's historical scrap value which is: $\$ 0.46 \mathrm{~m}$ at $x=25$ years. Notable is that as $n \rightarrow \infty$, any regression becomes more reliable. A regression line is recommended to be estimated by every shipping company at the end of every year from as many as possible observations of prices, for every ship according to her type, size and age.

The characteristic of the average fixed cost, due to depreciation, is falling as it is divided over by more and more ships (Figure 9).

Depreciation is important, because it covers-in this example-18.5\% of total cost. Depreciation affects also company's dividends, as well as net profits!

\subsection{A Proposed Depreciation Strategy}

Our proposal for depreciation is to determine it on ship's revenue per voyage. This proposal is due to the deep cyclicality of freight markets. According to Stopford (2009: p. 106) the peak years on average for 1947-2007 were 3 (for bulk era), and the trough years were 5. A vessel, of a vintage of 20 years, as our case, will face 2.5 cycles. The good times will last 7.5 years and the bad times 12.5.

${ }^{40} \$ 734,000$ per year. 
p.a.

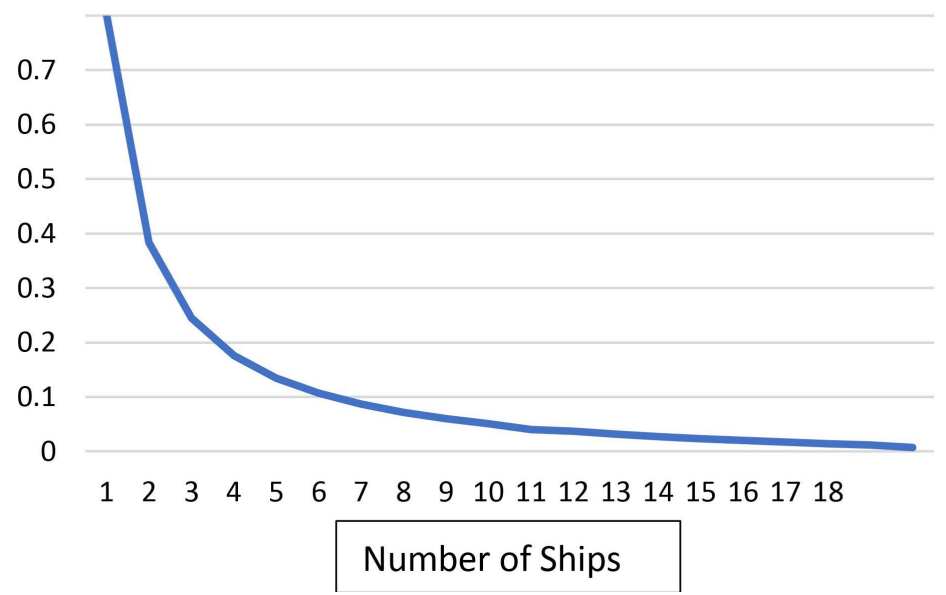

Figure 9. Average Fixed cost per ship due to depreciation. Source: author; data from Stopford (2009).

Example: in bad ${ }^{41}$ times the freight rate was $\$ 1.6 \mathrm{~m}$ per ship p.a. ( $\$ 4614 /$ day), as mentioned by Stopford, and for 20 ships this means $\$ 32 \mathrm{~m}$ each year, and for 12.5 bad years this equals $\$ 400 \mathrm{~m}$. In good years, let the freight rate be $\$ 2.68 \mathrm{~m}$ per ship p.a. ( $\$ 7729 /$ day) and for 20 ships times 7.5 years $=\$ 402 \mathrm{~m}$, a total of $\$ 802 \mathrm{~m}$. This allows for a $25 \%$ depreciation in bad years $(\$ 100 \mathrm{~m})$ and $36.51 \%$ depreciation in good years $(\$ 146.8 \mathrm{~m})$ (covering fleet's book value).

Our proposal assumed that shipping companies are free to depreciate ships at will - taking into account the market conditions. In UK, unlike USA, Japan and Germany, companies are permitted, by companies Act 1985, to write capital at a higher amount than its historical cost. This was due to inflation (FRS 15/IAS 16) (Reid \& Myddelton, 2005). Non-shipping companies seldom re-value their equipment and plant. Authorities also are only concerned for companies to use uniform regulations in their accounting practices so that an investor to understand the changes from year to year.

Unlike accountants, we are interested in an economic justice towards shipping companies, who often fall victims of cycles caused by others, and so the values of ships are recommended to be determined close to market ones at the time of forming company's balance sheet. These values can be determined by a regression line on data for the preceding 12 months, like the one presented above.

\subsection{A Recommended Business Policy}

We suggest to owners to sell 5 of the ships from $1^{\text {st }}-5^{\text {th }}$ vintage given their heavy depreciation (Table 3).

As shown, selling 5 ships company earned $\$ 92 \mathrm{~m}$ cash. Next, we will sell 5 ships in vintages $15^{\text {th }}-20^{\text {th }}$ due to their high operation cost.

As shown in Table 4 the company derived from these double sales $\$ 122.8 \mathrm{~m}$

${ }^{41} \mathrm{We}$ have no information of the type/size of ships, but we believe that the freight rate is below the real one. A Cape ship earned, in 2002, $\$ 6,000 /$ day times 346.75 days $=\$ 2,080,500$. 
Table 3. A sales program of 5 ships from younger vintages, 2002.

\begin{tabular}{cccccc}
\hline Ship age & Book value & Ops Costs m\$ p.a. & Ship age & Book value & Ops costs m\$ p.a. \\
\hline 1 & 20.0 & 1.10 & 4 & 17.6 & 1.25 \\
2 & 19.2 & 1.15 & 5 & 16.8 & 1.30 \\
3 & 18.4 & 1.20 & Total & 92.0 & 6 m p.a. \\
\hline
\end{tabular}

Source: author.

Table 4. A sales program of 5 ships from older vintages, 2002.

\begin{tabular}{cccccc}
\hline Ship age & Book value \$m & Ops Costs m\$ p.a. & Ship age & Book value \$m & Ops costs m\$ p.a. \\
\hline 16 & 8.0 & 1.85 & 19 & 5.6 & 2.00 \\
17 & 7.2 & 1.90 & 20 & 3.6 & 2.05 \\
18 & 6.4 & 1.95 & Total & $30.8 \mathrm{~m}$ & $9.75 \mathrm{~m}$ p.a. \\
\hline
\end{tabular}

Source: author.

$(\$ 30.8 \mathrm{~m}+\$ 92 \mathrm{~m})$. The new operations costs fell to $\$ 15.75$ p.a., half of what used to be ( $\$ 31.5)$. The capital cost (book value) also reduced to $\$ 124 \mathrm{~m}$ (vintages $\left.6^{\text {th }}-15^{\text {th }}\right)$ from $\$ 246.8 \mathrm{~m}$. Depreciation is now $\$ 4.96 \mathrm{~m}$ p.a. against $\$ 9.90 \mathrm{~m}$ p.a. The final outcome is:

\begin{tabular}{cclccc}
\hline Action & $\begin{array}{c}\text { Revenue } \\
\text { from sales }\end{array}$ & Action & Amount & Depreciation & $\begin{array}{c}\text { Revenue } \\
\text { From market }\end{array}$ \\
\hline Sell 10 ships & $\$ 122.8 \mathrm{~m}$ & Lower ops cost & $\begin{array}{c}\$ 315 \mathrm{~m} \text { required } \\
\text { for 20 years }\end{array}$ & $\begin{array}{c}\$ 99.2 \mathrm{~m} \text { for } 20 \\
\text { years on } \$ 124 \mathrm{~m}\end{array}$ & $\begin{array}{c}320 \mathrm{~m}(1.6 \times 20 \\
\text { years } \times 10 \text { ships })\end{array}$ \\
\hline
\end{tabular}

As shown, the smaller size of the company with 10 ships now, provides profits of $\$ 28.6 \mathrm{~m}$. This situation is better than the original one of laying-10 ships-up for a time not stated and at a cost also not stated. Still the ops costs are high.

\subsection{Empirical Evidence Concerning Greek Shipowners' Depreciation Policy}

A questionnaire sent (Malafouris, 2006), showed that from the 45 Greek shipping companies asked, $32 \%$ of the large ones ( $\geq 16$ ships) applied depreciation, $32 \%$ of the medium ones ( 6 - 15 ships) and $36 \%$ of the small ( $1-5$ ships). Those that applied depreciation stated that found no particular benefit.

Forty-four \% of the companies, which managed and owned ships, applied depreciation. The managing ones covered $36 \%$. The $24 \%$ of these companies followed IAS. Thirty-one \%, in general, applied IAS. Companies listed in Nasdaq applied US GAAP. The depreciation decision was taken by the board of directors $(60 \%)$.

Shipping companies in Stock Exchanges, or those requiring finance from the banks, they have to apply depreciation (99\%)! The special surveys expenses amortized in 4 years and certain companies applied different UL for single hulls 
(25 years) and double hulls (30 years). The initial expenses for new-buildings are amortized during the 1st voyage, while the improvement expenses in 3 years.

Most shipping companies used the straight-line method. $61.3 \%$ of the respondents answered that depreciation helped company's viability, as depreciation paid for a marine accident! Important is, what we have called "legal obsolescence", meaning expenses that are imposed by the new regulations imposed by IMO from time to time.

\section{Conclusion}

Capital becomes productive, in money terms, if the buying/building price of it falls, requiring as a result a lower depreciation ${ }^{42}$ amount, and a lower return on book value!

A great paradox is that during a recent depression, which started in end-2008, and a pandemic, which started in 2019, a number of citizens became extremely richer! Concurrently, the new poor increased, the homeless and the unemployed multiplied...

Searching the literature, we found that Keynes, since 1936, mentioned the above issues in his last chapter of general theory as the outstanding faults of economic society. And these, remained outstanding for more than 85 years ... so far!

We dared to say, out of our experience, that the economic man seeks to exploit the economic system for his/her personal benefit, applying: the "law of supply", "the willingness to pay", "the law of demand", and the "homogeneity of products and services" and by paying the women less for equal work than men.

In ships, the vintage characteristic is dominant. Moreover, economists who followed Keynes and wanted to make his unemployment theory, a growth theory, mainly between 1953 and 1970, paid attention to the fact that capital as agent of growth and as mean of embodied innovating technical progress, gets less productive as age increases. We have cross-examined the capital theory with that of shipping industry. True is that a great deal of substitution can be possible in shipping between capital and labor, after capital construction...

For our purpose, we found in the literature apropos data to build a microeconomic vintage shipping model for a shipping company. This company, owning 20 ships with varying vintages, manifested the importance that a high capital cost, and a fixed cost, can have on the profitability of the company.

We proved that not only the cost of operating a fleet matters, but also depreciation. Shipping companies have the privilege to be always in the long-run as their capital can change in say 1 - 3 months, through sales/purchases, laid-up and scrapping! But the bad luck of shipping companies is that no one, or few, understand that these companies live in frequent deep cycles and thus they have to follow different depreciation strategies, as we showed.

\footnotetext{
${ }^{42}$ The value of assets falls due to wear and tear. This means that capital is consumed during production creating a cost, before net profits, and taxation.
} 
We showed also that the microeconomic model of the main stream economics can apply also to shipping microeconomics, having the same principles, although we reached a different policy than that of Stopford, and a different definition of marginal cost. In fact, we strongly underlined that the economies of scale, (due to a falling average cost), lead to an average cost lower than marginal cost and this provides losses!

Depreciation invented so that to devote profits, which saved, to recoup money to buy a sister ship, when the old one becomes un-useful for a number of reasons!

Shipping companies were left loose vis-à-vis depreciation obligations for many decades, but banks, charterers as well Stock Exchanges, placed limits to the length of the useful life of ships, along with IAS/US GAAP/FRS. Authorities are concerned about providing a comparable picture from year to year for every company to those interested, and thus they demand uniform and pre-known depreciation rules and methods, because depreciation affects net profits, dividends and taxes!

Our effort, however, was to propose a depreciation according to market conditions by using a regression line between age of the ship and her historical price. Our philosophy is that when freight markets are good, an increased depreciation to be applied, and when they are bad, a limited one to be applied. This takes cyclicality of shipping markets into account. An empirical research showed that almost $1 / 3$ of the Greek shipping companies responded, applied depreciation, and more than $61 \%$ used depreciation funds... to face a marine accident!

Shipping companies must have the lowest possible total cost (variable + fixed) through a strategy of building or buying ships at rock bottom prices. Moreover, during each year, a regression line of best fit for the last 12 months to be estimated to determine age and market value of the ships one owns or wants to buy or even to build!

Our personal opinion is that depreciation may provide funds for cropping-up opportunities. Given that excessive depreciation antagonizes dividends, shareholders may not like it. The fair treatment of depreciation we reckon is that it has to be considered and treated as company's saving, as really is, deserving a strategy as shown.

\section{Conflicts of Interest}

The author declares no conflicts of interest regarding the publication of this paper.

\section{References}

Bilas, R. A. (1967). Microeconomic Theory: A Graphical Analysis. McGraw-Hill Book Company.

Blaug, M. (1997). Economic Theory in Retrospect (5th ed.). Cambridge University Press. 
https://doi.org/10.1017/CBO9780511805639

Buckley, J. J. (2008). The Business of Shipping (8th ed.). Cornell Maritime Press.

Cheng, P. C. (1979). Financial Management in the Shipping Industry. Cornell Maritime Press, Inc.

Evans, J. J. (1989). Replacement, Obsolescence and Modifications of Ships. Maritime Policy \& Management, 16, 223-231. https://doi.org/10.1080/03088838900000061

Goulielmos, A. M. (2018). The Economics of Wealth According to Economic and Religious Principles. Modern Economy, 9, 1465-1489.

https://doi.org/10.4236/me.2018.98093

Goulielmos, A. M. (2021). Why the Perfect Timing Achieved by the Managers of Shipping Companies Is So Important. Modern Economy, 12, 597-622.

https://doi.org/10.4236/me.2021.123031

Hansen, A. H. (1953). A Guide to Keynes. McGraw-Hill Book Company.

Harcourt, G. C., \& Laing, N. F. (1971). Capital and Growth: Selected Readings (Penguin Modern Economics Readings S.). Penguin Books Ltd.

Hughes, C. (1996). Ship Performance: Technical, Safety, Environmental and Commercial Aspects (2nd ed.). LLP.

Johansen, L. (1959). Substitution versus Fixed Production Coefficients, in the Theory of Economic Growth: A Synthesis. Econometrica, 27, 157-176.

https://doi.org/10.2307/1909440

Johansen, L. (1961). A Method for Separating the Effects of Capital Accumulation and Shifts in Production Functions upon Growth in Labor Productivity. Economic Journal, 71, 775-782. https://doi.org/10.2307/2228249

Keynes, J. M. (1936). The General Theory of the Employment Interest and Money. Harcourt Brace Jovanovich.

Lloyd's of London Press Ltd, a 2-Day Conference 1988, May 3-4, London Gloucester Hotel, Shipping Finance-Options \& Opportunities for the 1990s, Speakers' Papers. Speech of Dawes C. Vice President “Gotaas Larsen Sh. Corp.”, Bermuda.

Malafouris, D. P. (2006). The Treatment and the Importance of Depreciation in Shipping Accounting. Unpublished Master Degree Thesis, Department of Maritime Studies University of Piraeus, November, Copy Available from the Author.

Marshall, A. (1920). Principles of Economics: An Introductory Volume (8th ed.). Macmillan \& Co Ltd.

Menta, G., Wolff, E. N., \& D’Ambrosio, C. (2021). Income and Wealth Volatility: Evidence from Italy and the US I the Past Two Decades. The Journal of Economic Inequality, 19, 293-313. https://doi.org/10.1007/s10888-020-09473-4

Pearce, D. W. (1992). Macmillan Dictionary of Modern Economics (4th ed.). Macmillan Education. https://doi.org/10.1007/978-1-349-22136-3 15

Priesmeyer, H. R. (1992). Organizations and Chaos: Defining the Methods of Nonlinear Management. Quorom Books.

Reid, W., \& Myddelton, D. R. (2005). The Meaning of Company Accounts (8th ed.). Gower, VT USA.

Ricardo, D. (1951-1973). The Works and Correspondence of David Ricardo, Sraffa ed., Cambridge University Press, Vol. 1: Principles of Political Economy and Taxation.

Robinson, J. (1966). The Accumulation of Capital. Macmillan.

Robinson, J., \& Eatwell, J. (1973). An Introduction to Modern Economics, Revised Edi- 
tion. McGraw-Hill Book Company.

Salter, W. E. G. (1969). Productivity and Technical Change: With an Addendum by W. B. Reddaway. University Press.

Smith, A. (1910). The Wealth of Nations, with Introduction by D.D. Raphael, Everyman's Library (1991).

Stopford, M. (2009). Maritime Economics (3rd ed.). Routledge. https://doi.org/10.4324/9780203891742

Townsend, H. (1995). Foundations of Business Economics: Markets and Prices. Routledge. 